\title{
910 エルボ下流での超音波流量計による流量計測
}

\section{Measurement by Ultrasonic Flowmeter Located Downstream of Elbow}

\section{○正 文字秀明（筑波大）}

Hideaki Monji, University of Tsukuba

\author{
中谷武史（筑波大）
}

Takeshi Nakatani, University of Tsukuba

\section{瀬戸優貴（筑波大）}

\begin{abstract}
This paper deals with measurement error of an ultrasonic flowmeter located at downstream of an elbow. Velocity fields after the elbow were measured by PIV and the output of the flowmeter was estimated. The measurement error was small when a measurement line where a sound plus propagated was taken in a plane including the elbow's curve, comparing with the case of the measurement line was perpendicular to the elbow's curve plane. The error of the measurement was about $5 \%$ at $20 D$ downstream from the elbow ( $D$ : the diameter of the pipe). A straightener of the flow was useful to decreasing the error jut after the elbow but not after $20 D$.
\end{abstract}

Key Words: Flow Measurement, Flow Rate, Error, Velocity Profile, Entrance Region

\section{1.はじめに}

一般的に高効率化や省スペースのためにシステムの小型 化が求められるが、近年の流体を含むシステムでは流量計測 機器のための助走区間が十分に取れない場合も出てきた。本 研究は、そのような場合を想定し、エルボ下流の助走区間に 超音波流量計を設置した場合の計測誤差について調べ、計測 の可能性について検討した。

本研究で対象とした超音波流量計は、Fig.1 に示寸様に、 円管の流れ方向に位置の異なった $2 つ$ 超音波送受信子間 を超音波が伝播する時間から流量を推定するものである 1$)$ 超音波が伝播する経路（測線）上の流体速度は一定ではない ため、伝播時間から測線上平均流速を求め、実際の流量を推 定する。このとき、良く発達した流れであれば測線上の速度 分布と害流量の関倸が既知のため、計測流量の精度は良い。 しかし、エルボ下流の助走区間の様に偏流を含む場合は測線 速度分布が流量や流量計設置位置により大きく変わる。また、 良く発達した流れに対して設定された流量計からの出力は 誤差を含むと予測される。

そこで、本研究では助走区間での超音波流量計の使用を検 討するため、流量計の計測誤差を実験的求めた。実験では流 量を変えエルボ下流の数点で径方向速度分布を PIV により 計測した。さらに、得られた速度分布に基づき超音波流量計 出力を推定し、それと真の流量を比較した。

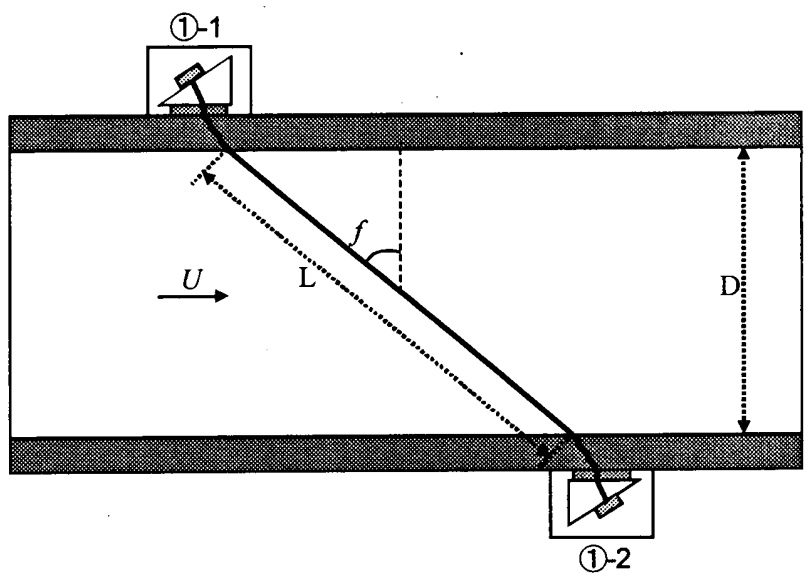

Fig.1 Setup of ultrasonic flowmeter (Z-method)

\section{2. 実験装置と計測方法}

実験では、Fig.2 で示されるエルボの入口および出口にそ れぞれ、内径 $D=26.5 \mathrm{~mm}$ 、長さ $2 \mathrm{~m}$ の FEP 製円管を接続し、 上流側から遠心ポンプにより水を流した。エルボ下流の FEP 製円管出口から水タンクまでさらに流路を接続し、大気中に 水を放出し、水タンクに貯めた。

エルボは曲がり面が水平面に含まれる様に設置した。直交 座標系を Fig.2 の様に取った。曲がり面は x-z 面内にあり、 重力方向は $\mathrm{y}$ 軸の負方向である。エルボは曲率比（曲率半径 と管内径の比） 0.93 のステンレス製の市販品であるが、内面 は 400 番のやすり仕上げてある。Fig.2 ではエルボ出口に多 孔式整流板 ${ }^{2)}$ が設置されているが、実験ではこれがある場合 とない場合について行った。

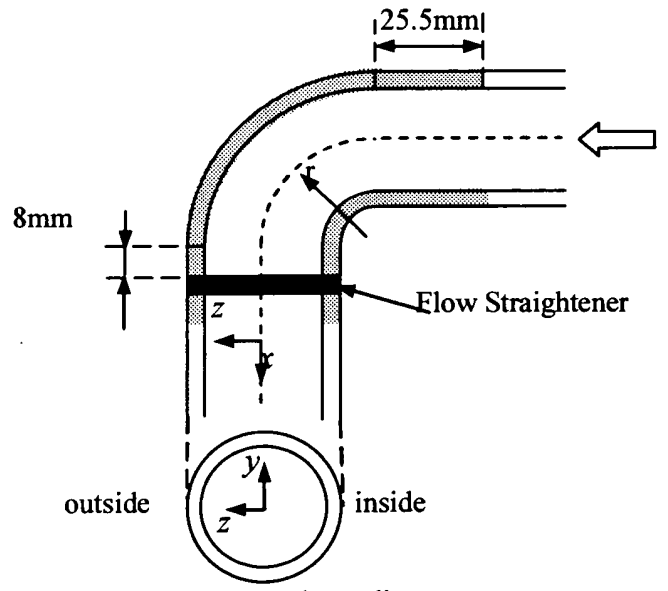

Fig.2 Elbow and coordinate system

計測部はエルボ出ロに接続した FEP 製円管部である。FEP の屈折率は水のそれに近く（水に対する相対屈折率 1.01）、 PIV で歪みの少ない画像を取得することができる。また、ウ オータジャケットも設置した。

Fig.2 の座標系で $\mathrm{x}-\mathrm{y}$ 平面および $\mathrm{x}-\mathrm{z}$ 平面内の速度場を PIV により求めた。 $80 \mathrm{~Hz}$ で 10 秒間速度場を計測し、その平均値 を求めた。また、エルボ入口手前でも PIVにより速度場を計 測し、速度分布より流量を算出した。 


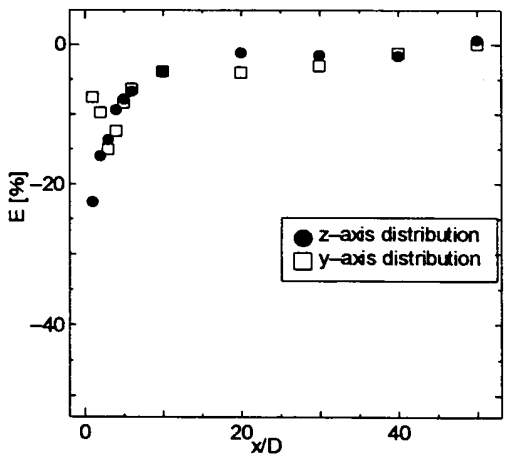

(a) without a flow straightener

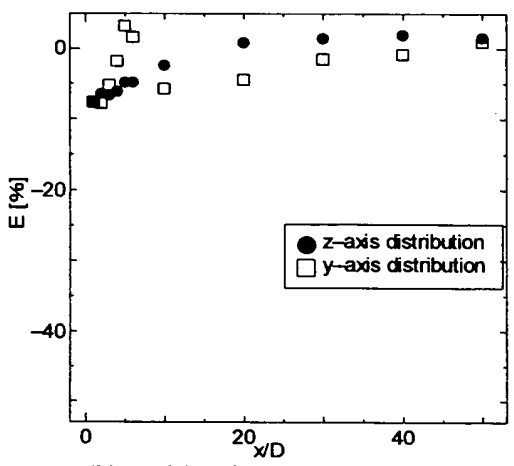

(b) with a flow straightener

Fig. 3 Error estimate of flow rate $\left(\operatorname{Re}=6.0 \times 10^{4}\right)$

\section{3. 実験結果}

実験で得られた速度分布を基に測線上の超音波伝播時間 を算出し、それを基に、超音波流量計出力 $Q$ を予測した。 $Q$ の予測には良く発達した乱流速度分布を基にした流量補正 係数を用いた。エルボ上流で計測した速度分布から算出した 流量 $Q_{r}$ と比較し、䛊差 $E$ を下記の式で算出した。

$$
E=\frac{Q-Q_{r}}{Q_{r}} \times 100 \quad[\%]
$$

Fig.3 (a)はエルボ出口に整流器を設置していない場合の誤 差評価結果で、測線が $\mathrm{x}-\mathrm{z}$ 平面にあり $\mathrm{z}$ 軸上の速度分布を用 いて伝播時間を算出した場合(z-axis distribution)と測線が $\mathrm{x}-\mathrm{y}$ 平面にあり $\mathrm{y}$ 軸上の速度分布を用いて伝播時間を算出した場 合(y-axis distribution)を示す。エルボ直後から 6D 付近まで y 軸上速度分布を用いた結果の方が誤差が少ない(絶対值が小 さい。これは速度分布形状が異なるためと考えられる ${ }^{3)}$ 。 軸上の速度分布はエルボの影響で 2 山分布になっているが、 それらの山の高さ(速度)はほぼ同じである。それに比べ、 軸上の速度分布はエルボの外周付近が大きく、顕著に偏流し ている。良く発達したな流れでは速度は軸対称で、レイノル ズ数が大きな場合は平坦化するため、 $\mathrm{y}$ 軸上の速度分布を用 いた場合の方が誤差が小さくなったと考えられる。

下流ではこれらの効果が小さくなり、エルボ下流からの距 離とともに誤差は少なくなる。例えば、5\%の誤差を許すの であれば 20D 下流に流量計を設置することができる。

Fig.3 (b)はエルボ出口に整流器を設置した場合の誤差を示 す。期待通り整流器により偏流は抑えられ、エルボ下流 10D ぐらいまでは誤差の絶対值は著しく小さくなった。Fig.4に $\mathrm{x}=1 \mathrm{D}$ の速度分布を示す。整流器の設置により偏流が抑えら れているのが分かる。しかし $\mathrm{z}$ 軸上の速度分布を用いた場合 にはエルボ下流 40D 付近でも誤差があり、整流器を設置しな い場合に比べても大きい。この理由としては、Fig.5 に示す
様に整流器を用いた場合には偏流の影響がまだ残っており 良く発達した速度分布にはなっていないことが考えられる。

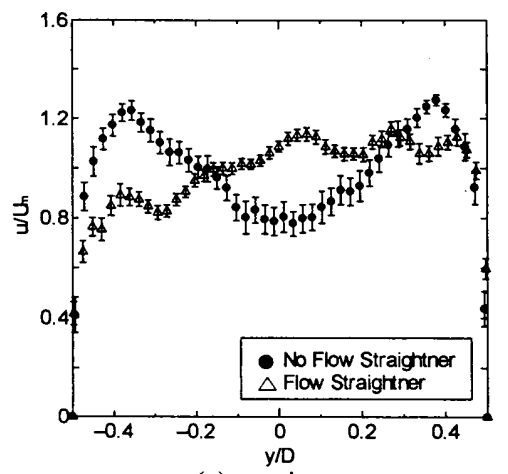

(a) y-axis

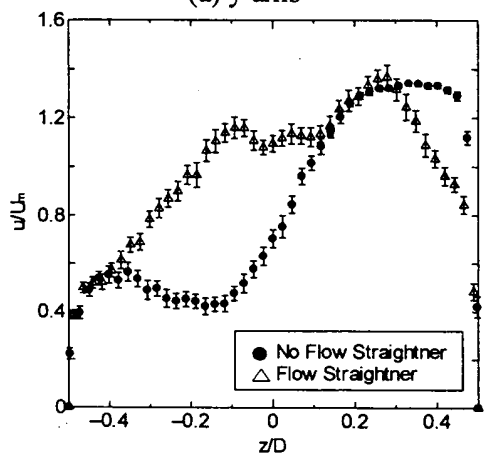

(b) z-axis

Fig. 4 Velocity distribution $\left(1 \mathrm{D}, \mathrm{Re}=6.0 \times 10^{4}\right)$

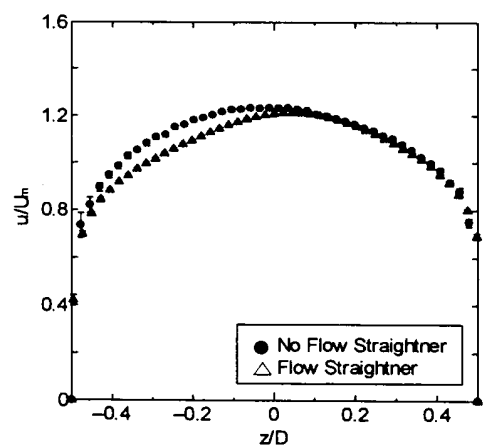

(b) z-axis

Fig. 5 Velocity distribution $\left(50 \mathrm{D}, \mathrm{Re}=6.0 \times 10^{4}\right)$

4. おわりに

エルボ下流に超音波流量計を設置した場合、その計測精度 について以下のことが分かった。

・5\%程度の誤差を認めるならば、エルボ下流 $20 \mathrm{D}$ 付近にも 流量計を設置することができる。

・整流器を用いるとエルボ直後では計測精度の向上が見込ま れるが、20Dより下流では精度は変わらないか、または逆に 悪くなることがある。

\section{参考文献}

1）日本機械学会、技術資料流体計測法、(1985)， 207.

2) Akashi, K., et al., Proc. of IMEKO Symposium on Flow Measurement and Control in Industry, (1979), 279.

3) 中谷、文字、茨城講演会講論集、(2009), 225. 